\title{
Clinical features and outcomes of COVID-19 in patients with rheumatic diseases treated with biological and synthetic targeted therapies
}

From the beginning of the COVID-19 pandemic, more than 4.7 million cases have been detected in the world, Spain being one of the countries hardest hit by the SARS-CoV-2. ${ }^{1}$ The role of the immune system and immunomodulatory therapies in the evolution of this infection is still controversial. ${ }^{2}$ The study of patients with rheumatic and musculoskeletal diseases (RMDs) such as rheumatoid arthritis (RA), spondyloarthropathies (SpA) or systemic lupus erythematosus, treated with immunomodulatory therapies is essential to understand the prognosis of COVID-19 in this specific population and to the management of these patients.

BIOBADASER is a multicentre prospective observational registry promoted by the Spanish Society of Rheumatology (SER) and supported by the Spanish Agency of Drugs and Medical Devices. It is aimed at assessing safety in patients with RMDs starting treatment with any biological (bDMARD) or targeted synthetic diseasemodifying antirheumatic drug (tsDMARD). More than 6600 patients are prospectively followed up in BIOBADASER 3.0.

This report describes the clinical characteristics and outcomes of patients with COVID-19 in BIOBADASER. We have identified 41 patients with RMDs treated with bDMARD and tsDMARD diagnosed of COVID-19 at 15 hospitals in the registry. Thirty-one patients were diagnosed because positive PCR test for SARS-CoV-2, and 10 patients because a highly compatible clinical picture and close contact with confirmed positive cases. Table 1 shows baseline characteristics of the patients. Twenty-five (61.0\%) patients were female and $16(39,0 \%)$ male, with a mean age of 59.4 years. They had long-standing (12.8 years) refractory (three previous bDMARD/ tsDMARDs) diseases with 5.7 years of bDMARD/tsDMARD therapy duration. Twenty-one patients (51.2\%) had RA. Comorbidities included hypertension (36.6\%), past or current smoker (36.8\%), diabetes $(9.8 \%)$ and high body mass index (BMI) $\left(27.7(5.6) \mathrm{kg} / \mathrm{m}^{2}\right.$ mean (SD)). Eighteen patients (43.9\%) were using TNF inhibitors, seven JAK inhibitors (17.1\%, 9.8\% baricitinib and 7.3\% tofacitinib) and five (12.2\%) IL-6 inhibitors. Seventeen (41.5\%) patients were using methotrexate and four $(9,8 \%)$ hydroxychloroquine.

Three patients died (7.3\%); a 63-year-old RA male on anakinra-plus prednisone $5 \mathrm{mg}$ /day-(comorbidities: smoker, BMI 34.6); a 56-year-old SpA female on secukinumab-no glucocorticoids-(past smoker, BMI 28.4) and a 91-year-old vasculitis female on rituximab-plus prednisone $5 \mathrm{mg} /$ day-(hypertension). Hospitalisation was required in 28 patients $(68.3 \%)$ and intensive care unit (ICU) admission in 6. Thirty-five (85.4\%) patients are fully recovered at the moment of this analysis, and three patients are still hospitalised, none in ICU.

Data on COVID-19 in patients with RMDs is still scarce..$^{3-6}$ Because of the rapid evolution of the pandemic, it is important to accrue information on the clinical course of rheumatic patients on bDMARD/tsDMARDs developing COVID-19. The reduced number of patients in our study limits the possibility of drawing solid conclusions. However, these findings point in the direction that COVID-19 course and mortality in patients 
Table 1 Clinical features and treatments in patients with rheumatic diseases on targeted therapies with the diagnosis of COVID-19

\begin{tabular}{|c|c|c|c|c|}
\hline Variable & RA & SpA & Other rheumatic diseases & Total \\
\hline $\mathrm{N}$ & 21 & 12 & 8 & 41 \\
\hline Age at COVID-19 onset, years (SD) & $61.3(13.9)$ & $57.1(11.5)$ & $57.1(23.9)$ & $59.4(15.6)$ \\
\hline Sex, female, $n(\%)$ & $14(66.6)$ & $5(41.7)$ & $6(75.0)$ & $25(61.0)$ \\
\hline Disease duration (time since rheumatic diagnosis to COVID-19), years (SD) & $12.0(8.3)$ & $15.0(14.2)$ & $11.4(7.9)$ & $12.8(9.8)$ \\
\hline Time with bDMARDs/tsDMARDs (time since beginning of treatment to COVID-19), years (SD) & $5.8(5.2)$ & $5.3(5.8)$ & $5.7(9.6)$ & $5.7(5.7)$ \\
\hline \multicolumn{5}{|l|}{ Comorbidities and risk factors } \\
\hline Charlson index, mean (SD) & $2.5(1.6)$ & $2.3(1.7)$ & $3.4(3.1)$ & $2.6(2.0)$ \\
\hline BMI, mean (SD) & $27.9(5.1)$ & $29.4(4.7)$ & $25.2(7.5)$ & $27.7(5.6)$ \\
\hline Hypertension, n (\%) & $6(28.6)$ & $5(41.7)$ & $4(50.0)$ & $15(36.6)$ \\
\hline \multicolumn{5}{|l|}{ Smoking status, n (\%) } \\
\hline Never smoker & $14(66.7)$ & $8(66.7)$ & $5(62.5)$ & $27(65.8)$ \\
\hline Current smoker & $2(9.5)$ & $0(0.0)$ & $2(25.0)$ & $4(9.8)$ \\
\hline Former smoker & $5(23.8)$ & $4(33.3)$ & $1(12.5)$ & $10(24.4)$ \\
\hline \multicolumn{5}{|l|}{ COVID-19 diagnosis, evolution and outcome } \\
\hline \multicolumn{5}{|l|}{ COVID-19 diagnosis, n (\%) } \\
\hline Confirmed cases (positive PCR test) & $16(76.2)$ & $8(66.7)$ & $7(87.5)$ & $31(75.6)$ \\
\hline Suspicious cases (highly compatible clinical picture) & $5(23.8)$ & $4(33.3)$ & $1(12.5)$ & $10(24.4)$ \\
\hline \multicolumn{5}{|l|}{ COVID-19 outcome } \\
\hline Recovered without sequelae & $18(85.7)$ & $11(91.7)$ & $6(75.0)$ & $35(85.4)$ \\
\hline Not yet recovered & $2(9.5)$ & $0(0.0)$ & $1(12.5)$ & $3(7.3)$ \\
\hline Death & $1(4.8)$ & $1(8.3)$ & $1(12.5)$ & $3(7.3)$ \\
\hline Hospitalisation, n (\%) & $16(76.2)$ & $8(66.7)$ & $4(50.0)$ & $28(68.3)$ \\
\hline Intensive care unit, $\mathrm{n}(\%)$ & $4(19.0)$ & $2(16.7)$ & $0(0.0)$ & $6(14.6)$ \\
\hline \multicolumn{5}{|l|}{ Rheumatic disease: treatment and clinical features } \\
\hline Last DAS-28 available (previous to COVID-19), mean (SD) & $3.9(1.4)$ & $3.3(1.3)$ & - & $3.6(1.4)$ \\
\hline \multicolumn{5}{|l|}{ bDMARD/tsDMARDs previous to COVID-19), $\mathrm{n}(\%)$} \\
\hline TNF inhibitors & $7(33.3)$ & $7(58.3)$ & $4(50.0)$ & $18(43.9)$ \\
\hline Anti-IL6 monoclonal antibodies & $3(14.3)$ & $0(0.0)$ & $2(25.0)$ & $5(12.2)$ \\
\hline Anti-CD20 monoclonal antibodies & $2(9.5)$ & $0(0.0)$ & $1(12.5)$ & $3(7.3)$ \\
\hline Anti-IL1 monoclonal antibodies & $1(4.8)$ & $0(0.0)$ & $0(0.0)$ & $1(2.4)$ \\
\hline Anti-IL17A monoclonal antibodies & $0(0.0)$ & $5(41.7)$ & $0(0.0)$ & $5(12.2)$ \\
\hline Abatacept & $1(4.8)$ & $0(0.0)$ & $1(12.5)$ & $2(4.9)$ \\
\hline JAK inhibitors & $7(33.3)$ & $0(0.0)$ & $0(0.0)$ & $7(17.1)$ \\
\hline Baricitinib & $4(9.0)$ & $0(0.0)$ & $0(0.0)$ & $4(9.8)$ \\
\hline Tofacitinib & $3(14.3)$ & $0(0.0)$ & $0(0.0)$ & $3(7.3)$ \\
\hline Number of previous bDMARD/tsDMARDs, mean (SD) & $4.2(2.9)$ & $2.0(1.0)$ & $1.6(0.7)$ & $3.0(2.4)$ \\
\hline \multicolumn{5}{|l|}{ Use of concomitant csDMARDS } \\
\hline Methotrexate & $11(52.4)$ & $4(33.3)$ & $2(25.0)$ & $17(41.5)$ \\
\hline Hydroxychloroquine & $2(9.5)$ & $0(0.0)$ & $2(25.0)$ & $4(9.8)$ \\
\hline Others & $0(0.0)$ & $2(16.7)$ & $0(0.0)$ & $2(4.9)$ \\
\hline Monotherapy & $12(57.1)$ & $6(50.0)$ & $4(50.0)$ & $22(53.7)$ \\
\hline Use of glucocorticoids, $n$ (\%) & $13(61.9)$ & $2(16.7)$ & $5(62.5)$ & $20(83.3)$ \\
\hline Dose of glucocorticoids (before COVID-19), mg, mean (SD) & $5.5(3.3)$ & $7.5(2.1)$ & $6(2.2)$ & $5.8(2.9)$ \\
\hline Concomitant use of NSAIDs, $n$ (\%) & $7(33.3)$ & $3(25.0)$ & $0(0.0)$ & $10(24.4)$ \\
\hline
\end{tabular}

bDMARDs, biological disease-modifying antirheumatic drugs; BMI, body mass index; n, number of patients; NSAIDs, non-steroidal anti-inflammatory drugs; RA, rheumatoid arthritis; SpA, spondyloarthropathies; tsDMARDs, targeted synthetic disease-modifying antirheumatic drugs.

with RMDs treated with $\mathrm{b} / \mathrm{tsDMARD}$ do not differ from the general population $(12.0 \%$ mortality rate and hospitalisation rate $53.6 \%$ by COVID-19 in Spain ${ }^{1}$ ). Of interest, these high mortality and hospitalisation rates are likely due to a diagnostic bias with PCR testing reserved for the most symptomatic patients, as suggested by a recent (unpublished) report by the Spanish Ministry of Health showing a prevalence of IgG seroconversion to SARS-Cov-2 of 5\% in Spain. That is 10 times greater than the PCR confirmed cases (1). The present data, in addition to previous publications, is crucial to clarify the risks of patients with rheumatic diseases and their immunosuppressive medications. Doubtlessness, additional studies are still needed. To this end, the SER is prospectively collecting information on COVID-19 in three registries (BIOBADASER, RELESSER and CARMA) in more than 9000 patients with rheumatic diseases.
Carlos Sanchez-Piedra, ${ }^{1}$ Cesar Diaz-Torne $\odot{ }^{2}$ Javier Manero, ${ }^{3}$ José M Pego-Reigosa, ${ }^{4}$ Íñigo Rúa-Figueroa $\odot{ }^{5}$

Miguel A Gonzalez-Gay $\odot^{6}$, Juan Gomez-Reino, ${ }^{7}$ Jose M Alvaro-Gracia $\odot{ }^{8}$ On behalf of the BIOBADASER study group

${ }^{1}$ Research Unit, Sociedad Española de Reumatologia, Madrid, Madrid, Spain ${ }^{2}$ Rheumatology, Hospital de la Santa Creu i Sant Pau, Barcelona, Spain ${ }^{3}$ Rheumatology, Hospital Universitario Miguel Servet, Zaragoza, Aragón, Spain ${ }^{4}$ Rheumatology, Complejo Hospitalario de Vigo Hospital Xeral, Vigo, Galicia, Spain ${ }^{5}$ Rheumatology, Hospital Universitario Insulsar Gran Canaria Doctor Negrin, Las Palmas de Gran Canaria, Spain

${ }^{6}$ Rheumatology, Hospital Universitario Marqués de Valdecilla Servicio de Medicina Interna, Santander, Cantabria, Spain

${ }^{7}$ Complejo Hospitalario Universitario de Santiago de Compostela, Santiago de Compostela, Galicia, Spain

${ }^{8}$ Rheumatology, Hospital General Universitario Gregorio Marañón, Madrid, Spain

Correspondence to Dr Jose M Alvaro-Gracia, Rheumatology, Hospital General Universitario Gregorio Marañón, 28007 Madrid, Spain; jalvarogracia@gmail.com 


\section{Handling editor Josef S Smolen}

Twitter Cesar Diaz-Torne @cesardiaztorne

Collaborators BIOBADASER study group: Dra. Maria Colazo (Hospital de Burgos), Dra Cristina Bohórquez (Hospital Universitario Príncipe de Asturias), Dr Javier del Pino (Hospital Universitario de Salamanca), Dra Paloma VelaCasasempere (Hospital General Universitario de Alicante), Dra Sagrario Bustabad (Hospital de Canarias), Dr Manuel Pombo-Suarez (Hospital Universitario de Santiago), Dr José Campos (Hospital Universitario Puerta de Hierro), Dra Raquel Martín-Domenech (Hospital General Universitario de Elda), Dra Cristina CamposFernandez (Hospital General Universitario de Valencia), Dra Rosa Roselló (Hospital San Jorge Huesca), Dra Lourdes Mateo (Hospital Universitario Germans Trias i Pujol).

Contributors CS-P and JA-G contributed to the design of the project interpretation and analysis of the data and writing of the manuscript. D-TC, JM and JG-R contributed to the collection of data, interpretation and analysis of the data and review of the manuscript. JMP-R, IR-F and MAG-G contributed to the interpretation of the data and review of the manuscript.

Funding The authors have not declared a specific grant for this research from any funding agency in the public, commercial or not-for-profit sectors.

Competing interests None declared.

Patient and public involvement Patients and/or the public were not involved in the design, or conduct, or reporting, or dissemination plans of this research.

Patient consent for publication Not required.

Provenance and peer review Not commissioned; externally peer reviewed.

\section{(2) \\ OPEN ACCESS}

This is an open access article distributed in accordance with the Creative Commons Attribution Non Commercial (CC BY-NC 4.0) license, which permits others to distribute, remix, adapt, build upon this work non-commercially, and license their derivative works on different terms, provided the original work is properly cited, appropriate credit is given, any changes made indicated, and the use is noncommercial. See: http://creativecommons.org/licenses/by-nc/4.0/.

(C) Author(s) (or their employer(s)) 2020. Re-use permitted under CC BY-NC. No commercial re-use. See rights and permissions. Published by BMJ.

\section{Check for updates}

To cite Sanchez-Piedra C, Diaz-Torne C, Manero J, et al. Ann Rheum Dis 2020;79:988-990.

Received 12 May 2020

Revised 21 May 2020

Accepted 22 May 2020

Ann Rheum Dis 2020;79:988-990. doi:10.1136/annrheumdis-2020-217948

\section{ORCID iDs}

Cesar Diaz-Torne http://orcid.org/0000-0001-6275-7699

Íñigo Rúa-Figueroa http://orcid.org/0000-0002-7894-1690

Miguel A Gonzalez-Gay http://orcid.org/0000-0002-7924-7406

Jose M Alvaro-Gracia http://orcid.org/0000-0002-0343-3747

\section{REFERENCES}

1 (CCAES) CdCdAyES.. Enfermedad POR nuevo coronavirus, COVID-19. Situación actual, 2020. Available: https://www.mscbs.gob.es/profesionales/saludPublica/ccayes/ alertasActual/nCov-China/documentos/Actualizacion_111_COVID-19.pdf [Accessed cited 2020 21/05/2020].

2 Neurath MF. Covid-19 and immunomodulation in IBD. Gut 2020;382:gutinl-2020-321269.

3 Monti S, Balduzzi S, Delvino P, et al. Clinical course of COVID-19 in a series of patients with chronic arthritis treated with immunosuppressive targeted therapies. Ann Rheum Dis 2020:79:667-8.

4 Haberman R, Axelrad J, Chen A, et al. Covid-19 in immune-mediated inflammatory diseases — case series from New York. N Engl J Med Overseas Ed 2020.

5 Favalli EG, Ingegnoli F, De Lucia O, et al. COVID-19 infection and rheumatoid arthritis: Faraway. so close! Autoimmunity reviews 2020;102523.

6 Gianfrancesco MA, Hyrich KL, Gossec L, et al. Rheumatic disease and COVID-19: initial data from the COVID-19 global rheumatology alliance provider registries. The Lancet Rheumatology 2020. 